\title{
Changes in Amino Acid and Amine Contents of Susceptible Tomato Cultivars Infected with Alternaria alternata Tomato Pathotype or Treated with AL-toxin*
}

\author{
Itsuo KaWAGUChI**, Noemi P. OrolazA**, Takashi Tsuge**, \\ Late Syoyo NishimurA** and Noriyuki DoKE**
}

\begin{abstract}
The changes in amino acid and amine contents of susceptible and resistant tomato cultivars infected with Alternaria alternata tomato pathotype or treated with its host-selective AL-toxin were investigated. AL-toxin has been known as a potential inhibitor of aspartate carbamoyltransferase (ACTase) in susceptible tomato plants. Inhibition of ACTase should result in the accumulation of aspartic acid in the susceptible plant treated with AL-toxin. In this study, however, no difference was observed in the amount of aspartic acid and other amino acids between toxin-treated and non-treated leaves of the susceptible and resistant cultivars until at least $24 \mathrm{hr}$ after treatment. In the susceptible tomato plants inoculated with spores at the base of the stem, amino acid contents in leaflets showing necrotic symptom were similar to that in corresponding leaflets without symptom. Aspartic acid content in symptom-developed leaflets was rather lower than that in symptom-less ones. These results do not support the hypothesis that AL-toxin inhibits ACTase. On the other hand, two amines, ethanolamine and phosphoethanolamine, markedly accumulated in susceptible tomato leaves 12 to $24 \mathrm{hr}$ after toxin treatment, but not in resistant ones. The increase in these amines was also observed in symptom-developing leaflets but not in symptomless ones of plants inoculated with the spores of the pathogen. These results suggest that AL-toxin induces disorder of metabolism related to these amines in susceptible tomato cells.
\end{abstract}

(Received December 4, 1990)

Key words: Alternaria alternata tomato pathotype, AL-toxin, amino acid, amine, Lycopersicon esculentum.

\section{INTRODUCTION}

Tomato cultivars (Lycopersicon esculentum Mill.) carrying the genotypes, asc/asc, are susceptible to Alternaria stem canker caused by Alternaria alternata tomato pathotype [A. alternata (Freis) Keissler f. sp. lycopersici $]^{1,7,10}$. This fungus produces AL-toxins (AAL-toxins) which are composed of four closely related molecular species, AL-toxin Ia (TA-1), Ib (TA-2), IIa (TB-1) and IIb (TB-2) ${ }^{6,10,19)}$. AL-toxins were reported as essential factors for the pathogenicity of A. alternata tomato pathotype ${ }^{6}$, and some findings about the mode of action have been reported $^{4,5,10,18)}$. Cytological studies of tomato leaves treated with AL-toxin revealed a disintegration of mitochondria and endoplasmic reticula ${ }^{18)}$. Some host-selective toxins induce almost immediate leakage of electrolytes from host cells, indicating disfunction of their plasma mem-

* This study was supported by Grant-in-Aid for Cooperative Research Nos. 01304014 (1989-1990) and 02304019 (1990-1991).

** Faculty of Agriculture, Nagoya University, Nagoya 464, Japan 名古屋大学農学部

The fourth author passed away on May 27, 1989. 
brane ${ }^{16,18,20)}$. However, such electrolyte leakage was not observed in tomato plants treated with AL-toxin ${ }^{4,10)}$. When the suspension-cultured cells of the susceptible tomato cultivar were exposed to the toxin, practically no significant changes were observed in respiration, uptake of $\left[{ }^{3} \mathrm{H}\right]$ pyruvate and its incorporation into protein, uptake of $\left[3-{ }^{14} \mathrm{C}\right]$ pyruvate and its incorporation into lipids and net synthesis of RNA and DNA ${ }^{4}$.

McFarland and Gilchrist have proposed that AL-toxins inhibit aspartate carbamoyltransferase (ACTase; EC 2.13 .2 ), which catalyzes the condensation of aspartic acid and carbamoyl phosphoric acid in the pathway of pyrimidine biosynthesis ${ }^{5,14}$. Their proposal is based mainly on the following observations: AL-toxins caused the accumulation of aspartic acid in susceptible tomato leaves; AL-toxins inhibited ACTase activity in the extracts from tomato seedlings in vitro; and supplement of certain pyrimidine precursors into toxin-treated tomato leaves protected the leaves from toxin damage. It is not known, however, whether the toxins could actually cause in vivo metabolic changes that are consistent with the ACTase inhibition. An experiment using cultured cells derived from susceptible tomato plants, failed to demonstrate the inhibition of aspartate carbamoyltransferase by AL-toxins ${ }^{4)}$.

In the present paper, we investigated the effects of AL-toxins on the metabolism of amino acids and amines in susceptible tomato leaves to extend our understanding of their mode of action.

\section{MATERIALS AND METHODS}

Plants. Tomato plants (Lycopersicon esculentum Mill.), susceptible cv. Mie First, intermediately susceptible cvs. First Power and Zuiko, and resistant cv. Saturn to A. alternata tomato pathotype were used as test plants. Plants were grown in pots under glass house condition.

Fungus. Isolate AL-4 of $A$. alternata tomato pathotype was obtained from a naturally infected tomato plant in Suzuka city, Mie Prefecture, Japan. The stock isolate was periodically transferred onto potato dextrose agar, and mature cultures were stored at $4^{\circ} \mathrm{C}$.

Preparation of inocula. Conidial suspensions were used as inocula. Isolate AL-4 of the tomato pathotype was grown at $28^{\circ} \mathrm{C}$ in light on V-8 juice agar' ${ }^{3)}$ for 7 days to induce sporulation. The spores formed on cultured mycelia were harvested by brushing the surface with an enamel brush and suspended in distilled water. The spore suspension was filtrated through two layers of cheese cloth, and then the spores were collected on filter paper by filtration.

Preparation of toxins. A. alternata tomato pathotype was still-cultured at $28^{\circ} \mathrm{C}$ for 20 days in light in $1,000 \mathrm{ml}$ Roux bottles, each containing $350 \mathrm{ml}$ of Richards' liquid medium ${ }^{8}$ ) supplemented with $0.1 \%$ yeast extract (Difco). Culture filtrate was harvested by filtration through two layers of cheesecloth and filter paper (Toyo No. 2). The culture filtrate was passed through Amberlite (XAD-4 or XAD-7, Organo Co., Ltd.) column $(30 \times 100 \mathrm{~mm})$. Toxic activity retained in the column was extracted with methanol. The extracts were evaporated in vacuo, dissolved in water and then extracted with ethyl acetate. The water phase was further extracted with equal volume of water-saturated $n$-butanol. Active fraction was detected in the $n$-butanol phase. To separate AL-toxins I and II, $n$-butanol extracts were subjected sequentially to Develosil Lop ODS (Nomura Chemical Co., Ltd.) column $(16 \times 160 \mathrm{~mm})$ and Bio-Gel P-2 (200-400 mesh, Bio-Rad Laboratories) column $(14 \times 680 \mathrm{~mm})$ chromatographies according to the method of Clouse and Gilchrist ${ }^{1}$. Toxin preparations from Bio-Gel P-2 were chromatographed on silica gel TLC (silica gel $60 / F_{254}, 0.25 \mathrm{~mm}$ in thickness, Merck) by developing with $n$-butanol: acetic acid:water $(4: 1: 1, \mathrm{v} / \mathrm{v} / \mathrm{v})$. AL-toxins I and II were detected on the developed TLC plate that reacted with ninhydrin at $R f$ values of 0.4 and 0.47 , respectively ${ }^{10)}$. AF-toxin and alternaric acid were kindly provided by S.-S. Lee and G. Langsdorf of our laboratory.

Bioassay. Toxin activity was detected by a detached-leaflet bioassay system. Leaflets 
were excised by cutting across the bases of the petioles and then placed on 9-cm discs of filter paper saturated with $3 \mathrm{ml}$ toxin solutions in plastic petri plates. The petri plates were sealed with parafilm and incubated at $25^{\circ} \mathrm{C}$ for 3 days in light. Leaf-disc bioassay was also employed. Leaf discs, $13 \mathrm{~mm}$ in diameter, were placed in multi-well plates containing $200 \mu \mathrm{l}$ of different concentrations of toxin in each well. The plates were sealed with parafilm and incubated at $25^{\circ} \mathrm{C}$ for 3 days in light. The necrotic areas were measured by an image analyzer, IBAS (Zeiss-Kontron Electronic Group).

Extraction of amino acids and amines. Tomato leaves were refluxed in $50 \mathrm{ml}$ of $70 \%$ ethanol for $4 \mathrm{hr}$ at $60^{\circ} \mathrm{C}$. The resulting solution was filtrated, and the residue was washed three times with $70 \%$ ethanol. The combined filtrates were evaporated in vacuo to dryness, redissolved in $5 \mathrm{ml}$ distilled water and centrifuged at $200 \times g$ for $5 \mathrm{~min}$. The supernatants were filtrated through $0.45 \mu \mathrm{m}$ filter and further passed through a column $(13 \times 35 \mathrm{~mm})$ of Dowex 5W-X8 (100-200 mesh, Dow Chemical Company). The column was washed with $20 \mathrm{ml}$ distilled water and then $20 \mathrm{ml}$ of $2 \mathrm{~N}$ ammonium hydroxide. The ammonium hydroxide eluate was evaporated in vacuo to dryness and dissolved in $2 \mathrm{ml}$ lithium citrate buffer ( $\mathrm{pH} \mathrm{2.2).} \mathrm{One}$ hundred $\mu 1$ portions of the solution were subjected to analysis of amino acids and amines by an amino acid analyzer, MLC-203 (ATTO). The amounts of amino acids and amines were represented as $\mathrm{nmol} / \mathrm{g}$ fresh weight of tomato leaves ${ }^{17)}$.

\section{RESULTS}

\section{Host-specific action of AL-toxin}

The biological activities of AL-toxins I and II were evaluated with four cultivars of tomato, cvs. Mie First, First Power, Zuiko and Saturn, by the bioassay systems using detached-leaflet (Fig. 1) and leaf disc (Fig. 2). There was no difference in the necrosis-inducing activities between AL-toxin I and AL-toxin II in both assay systems. In the detached-leaflet system, ALtoxins I and II induced veinal necroses on susceptible cv. Mie First at a concentration of 0.06 $\mu \mathrm{g} / \mathrm{ml}$. To induce veinal necroses on the leaves of intermediately susceptible cvs. First Power and Zuiko and resistant cv. Saturn, 100 and 2,000 times higher concentrations of the toxin were needed, respectively.

In the leaf-disc system, the phytotoxicity of the toxins was detected more sensitively than that in the detached-leaflet system. Both toxins I and II induced necroses on $12 \%$ area of the leaf discs of cv. Mie First at a toxin concentration of $0.04 \mu \mathrm{g} / \mathrm{ml}$. In the case of intermediately susceptible and resistant tomato cultivars, the minimum concentrations required to cause ne-

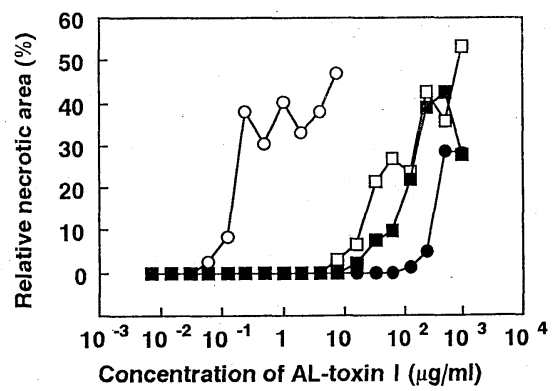

Fig. 1. Necrosis induction by AL-toxin I on the leaflets of four tomato cultivars ( $O$ : Mie First, $\square:$ First Power, $\square$ : Zuiko, $\bullet$ : Saturn). The necrotic area on the leaflet was measured 3 days after toxin treatment by IBAS-apparatus (Zeiss) and represents as \% of total leaf area. Each value represents the average of two experiments. Similar results to this figure were obtained using AL-toxin II. 


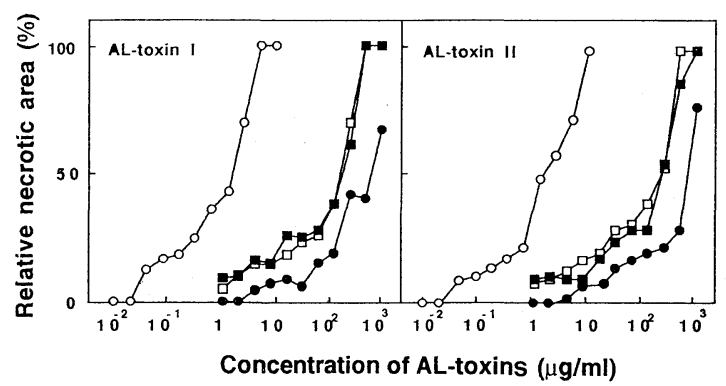

Fig. 2. Necrosis induction on the leaf discs $(13 \mathrm{~mm}$ in diameter) of four tomato cultivars $(O$ : Mie First, $\square$ : First Power, $\mathbf{\square}$ : Zuiko, : Saturn) by AL-toxin I and AL-toxin II. Each sample and experimental condition are the same as those in Fig. 1. Each value represents the average of four experiments.

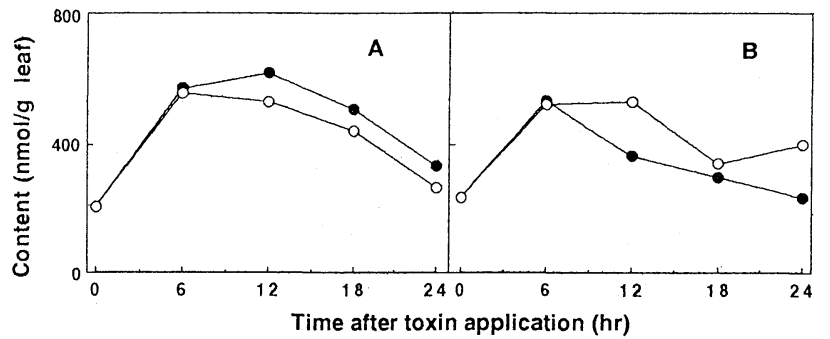

Fig. 3. Content of aspartic acid in tomato leaves of susceptible cv. Mie First (A) and resistant cv. Saturn (B) treated with $10 \mu \mathrm{g} / \mathrm{ml}$ of AL-toxin I (@) or distilled water (O). Each value represents the average of two experiments.

croses were about 25 and 100 times higher, respectively, as compared with that required for the susceptible one. The concentrations of toxins which induced necroses of more than $20 \%$ leaf area were 0.3, 30 and $250 \mu \mathrm{g} / \mathrm{ml}$ for tomato cultivars, susceptible (cv. Mie First), intermediately susceptible (cvs. First Power and Zuiko) and resistant (cv. Saturn), respectively. The sensitivity of susceptible tomato leaves to the toxins was almost the same, regardless of their growth stages (data not shown).

\section{Effects of AL-toxins on the contents of amino acids and amines}

In the proposed context of ACTase inhibition by AL-toxin ${ }^{5,14}$, we investigated whether the changes in the contents of 18 amino acids and 5 related compounds were brought about by AL-toxins and/or pathogen infection in the leaves of susceptible tomato. Tomato leaves (cvs. Mie First and Saturn) were treated with AL-toxin I $(10 \mu \mathrm{g} / \mathrm{ml})$ according to the method of detached-leaflet assay system. The content of each amino acid was determined at intervals after toxin treatment. There was no difference in the contents of aspartic acid (Fig. 3) and the other amino acids (Fig. 4) between toxin-treated and water-treated leaves of the susceptible and resistant cultivars for at least $24 \mathrm{hr}$ after treatment. In Fig. 4, the percentage of control was shown at $18 \mathrm{hr}$ after AL-toxin treatment. Also, there was no significant difference in the contents of amino acids when incubated at 6,12 and $24 \mathrm{hr}$ with AL-toxin $(10$ and $20 \mu \mathrm{g} / \mathrm{ml}$ ) (data not shown). The amino acid contents in symptom-developing leaflets of tomato plants (cv. Mie First) inoculated with the pathogen were also analyzed. Tomato plants were inoculated with spores at the base of the stem, and then compound leaves that showed slight interveinal necroses in the leaflets at one side (symptom-developing leaflet) but not on the other side (symptom-less leaflets) were selected. The content of aspartic acid in the symptom-developing leaflets was significantly lower than that in corresponding leaflets showing no symptoms (Fig. 5). Also, 


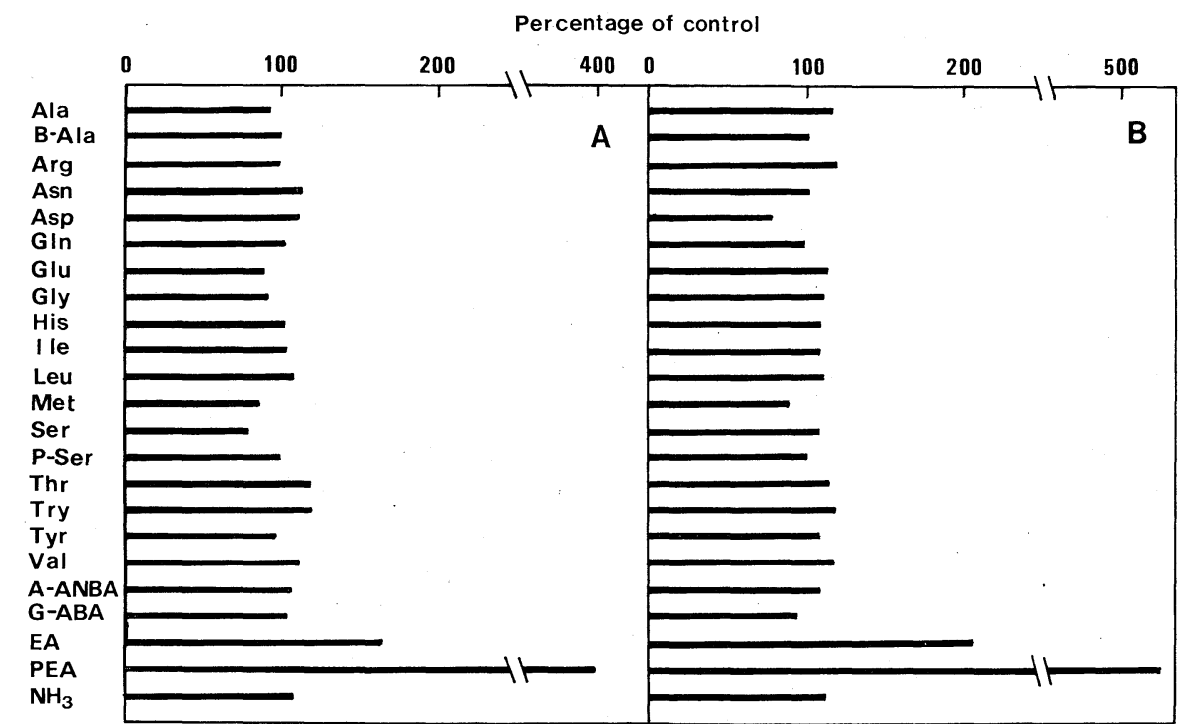

Fig. 4. Contents of amino acids and some related compounds in tomato leaves cv. Mie First treated with $10 \mu \mathrm{g} / \mathrm{ml}$ (A) and $20 \mu \mathrm{g} / \mathrm{ml}$ (B) of AL-toxin I for $18 \mathrm{hr}$. Each value represents as $\%$ of control and the average of two experiments.

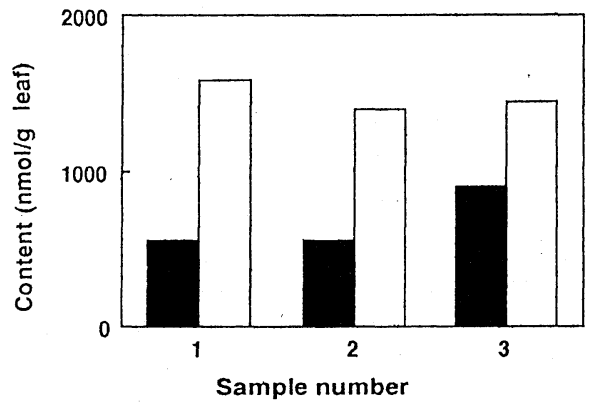

Fig. 5. Content of aspartic acid in the symptom-developed leaflet ( $\mathbf{a}$ ) and symptom-less leaflet $(\square)$ of tomato cv. Mie First after inoculation with spores of A. alternata tomato pathotype, isolate AL-4. Sample number indicates the leaflet position, wherein samples 1,2 and 3 were taken from the top to the lower part of the leaflet. Each value represents the mean of three experiments.

no significant difference was found in the content of other amino acids between symptom-appeared and symptom-less leaflets of the tomato plants (data not shown).

The changes in the contents of some amines in the toxin-treated tomato leaflets were also determined by using an amino acid analyzer ${ }^{9,17}$. Among amines detected, ethanolamine and phosphoethanolamine significantly increased in susceptible tomato leaflets from 12 to $24 \mathrm{hr}$ after treatment with AL-toxin I (Figs. 4 and 6). A similar trend of increase in these amines was observed in symptom-developing leaflets on plants following inoculation but not in the corresponding leaflets showing no symptoms (Fig. 7).

To confirm the specificity of such effect of AL-toxin in tomato plants, the contents of ethanolamine and phosphoethanolamine were also analyzed in other toxin-host plants combinations. One was the tomato-alternaric acid system in which tomato leaves of cv. Mie First were treated with alternaric acid $(10 \mu \mathrm{g} / \mathrm{ml})$ for $24 \mathrm{hr}$ at $25^{\circ} \mathrm{C}$ in light ${ }^{11)}$. The other was the 


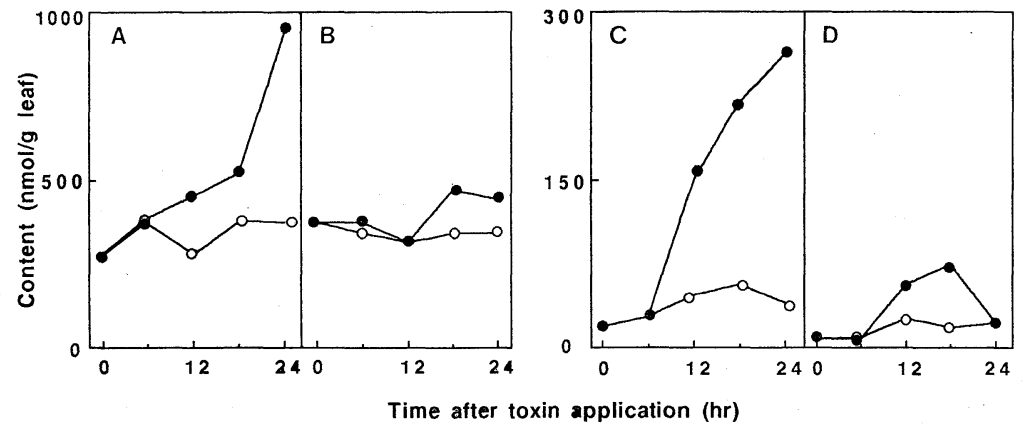

Fig. 6. Contents of ethanolamine (A and B) and phosphoethanolamine $(\mathrm{C}$ and $\mathrm{D})$ in tomato leaves of susceptible cv. Mie First (A and C) and resistant cv. Saturn (B and D) treated with $10 \mu \mathrm{g} / \mathrm{ml}$ of AL-toxin I (๑) or distilled water (O). Each value represents the mean of two experiments.

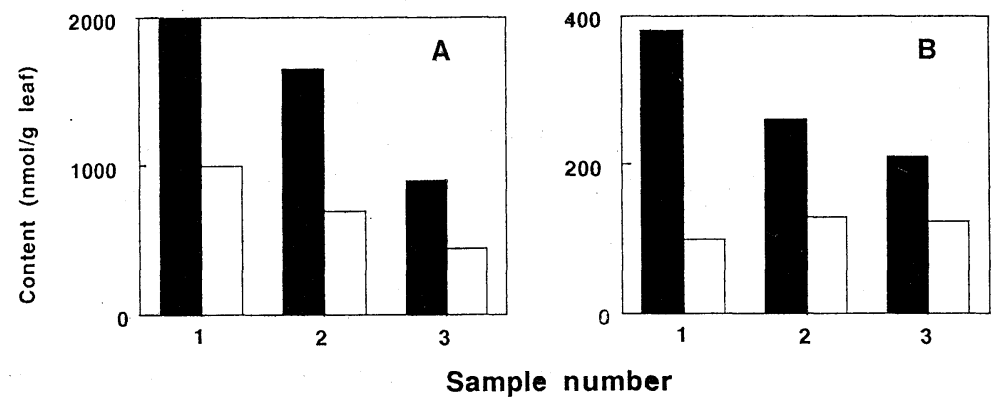

Fig. 7. Contents of ethanolamine (A) and phosphoethanolamine (B) in symptom-developing leaflet ( $\square$ ) and the symptom-less leaflet $(\square)$ of tomato cv. Mie First after inoculation with spores of $A$. alternata tomato pathotype, isolate AL-4. Each value and experimental condition are the same as those in Fig. 5. Each value represents the mean of three experiments.

strawberry-AF-toxin system in which the suspension-cultured cells were treated with AF-toxin $(0.5 \mu \mathrm{g} / \mathrm{ml})$ at $23^{\circ} \mathrm{C}$ for $4 \mathrm{hr}$ in light $\left.{ }^{12}\right)$. In both cases, the abnormal accumulations of ethanolamine and phosphoethanolamine were not demonstrated, although toxic damage to each plant cells was observed (data not shown).

\section{DISCUSSION}

In the present experiment, changes in the amount of aspartic acid were evaluated in the AL-toxin-treated leaves of susceptible and resistant tomato cultivars with reference to the hypothesis on the mode of action of AL-toxin in which AL-toxin was proposed as a potential inhibitor of ACTase ${ }^{5,14}$. Our results indicated that there is no significant difference in the amount of aspartic acid between the toxin-treated and untreated leaves and also between susceptible and resistant cultivars. If ACTase was inhibited by the toxin, abnormal accumulation of aspartic acid should be observed because it is the key enzyme in the pyrimidine biosynthetic pathway via conversion of aspartic acid and carbamoyl phosphoric acid to $N$-carbamoyl aspartic acid ${ }^{13)}$. Our results showed no effect of AL-toxins on aspartic acid content, hence do not support the previous proposal on the mode of action of AL-toxins ${ }^{5,14}$. We observed that symptom-devel- 
oping leaflets of susceptible tomato plants inoculated with the pathogen showed a pronounced decrease in the content of aspartic acid as compared to leaflets showing no symptoms. Since there is no significant changes in aspartic acid content in the AL-toxin treated leaflets, ACTase may not be the key site of action for AL-toxins in intact plants.

The abnormal accumulations of ethanolamine and phosphoethanolamine in toxin-treated susceptible tomato leaves were first demonstrated in this study. Both amines are known as the intermediate metabolites in the pathway of phospholipid biosynthesis in higher plants ${ }^{13}$. Phosphoethanolamine cytidyltransferase which is known to be localized in the endoplasmic reticulum catalyzes the step from phosphoethanolamine to CDP-ethanolamine ${ }^{15}$. If this enzyme was inhibited by AL-toxins, abnormal accumulations of these amines might be observed in the toxin-treated tissues. Phosphoethanolamine was also reported to be methylated and converted to phosphatidylcholine by using soybean and carrot root cells ${ }^{2}$. The inhibition of this step would also result in the accumulation of such amines. Although it was not shown which metabolic pathway was inhibited by AL-toxins, they may possibly disturb amine metabolisms because AL-toxins themselves are amines. The previous demonstration of disintegration of mitochondrial membrane and rough endoplasmic reticulum in susceptible tomato cultivars ${ }^{18)}$ may also suggest a disturbance in phospholipid metabolisms by AL-toxins. Further studies are needed to understand the exact mode of AL-toxins' action to the tomato cells.

We are grateful to Prof. K. Kohmoto, Laboratory of Plant Pathology, Tottori University, for valuable suggestion, Dr. T. Tashiro, Laboratory of Crop Science, Nagoya University, for helpful suggestion on amino acid analysis and Dr. K. Kawakita for valuable discussion.

\section{Literature cited}

1. Clouse, S.D. and Gilchrist, D.G. (1987). Interaction of the asc locus in $\mathrm{F}_{8}$ paired lines of tomato with Alternaria alternata f. sp. lycopersici and AAL-toxin. Phytopathology 77: 80-82.

2. Datko, A.H. and Mudd, S.H. (1988). Phosphatidylcholine synthesis: differing patterns in soybean and carrot. Plant Physiol. 88: 854-861.

3. Dhingra, O.D. and Sinclair, J.B. (1986). Culture media and their formulas. In Basic Plant Pathology Methods. CRC Press, Inc., Boca Raton. pp. 285-315.

4. Fuson, G. and Pratt, D. (1988). Effects of host-selective toxins of Alternaria alternata f. sp. lycopersici on suspension cultured tomato cells. Phytopathology 78: 1641-1648.

5. Gilchrist, D.G. (1983). Molecular modes of action. In Toxins and Plant Pathogenesis (Daly, J.M. and Deverall, B.J. eds.). Academic Press, Sydney. pp. 81-136.

6. Gilchrist, D.G. and Grogan, R.G. (1976). Production and nature of a host-specific toxin from Alternaria alternata f. sp. lycopersici. Phytopathology 66: 165-171.

7. Grogan, R.G., Kimble, K.A. and Misaghi, I. (1975). A stem canker disease of tomato caused by Alternaria alternata f. sp. lycopersici. Phytopathology 65: 880-886.

8. Johnson, A. and Booth, C. (1983). Mycological media and methods. In Plant Pathologists' Pocketbook, Second edition (Johnson, A. and Booth, C. eds.). The Cambrian News Ltd., Wales. pp. 393415.

9. Kawaguchi, I., Doke, N., Nishimura, S. and Kohmoto, K. (1989). Effect of AL-toxin on the amine and amino acid metabolism of susceptible tomato plant. Ann. Phytopath. Soc. Japan 55: 482-483 (Abstr. in Japanese).

10. Kohmoto, K., Virenda, S.M., Nishimura, S., Tagami, M. and Scheffer, R.P. (1982). New outbreak of Alternaria stem canker of tomato in Japan and production of host-selective toxins by the causal fungus. J. Fac. Agric. Tottori Univ. 17: 1-8.

11. Langsdorf, G., Furuichi, N., Doke, N. and Nishimura, S. (1990). Investigations on Alternaria solani infections: Detection of alternaric acid and a susceptibility-inducing factor in the spore germination fluid of A. solani. J. Phytopathol. 128: 271-282.

12. Lee, S.-S., Hotta, A., Tsuge, T., Nishimura, S., Nakatsuka, S. and Goto, T. (1989). Effects of AFtoxin on strawberry cultured cells. Ann. Phytopath. Soc. Japan 55: 483 (Abstr. in Japanese). 
13. Lehninger, A.L. (1975). Biosynthesis of pyrimidine nucleotides. In Biochemistry, Second ed (A. L. Lehninger, ed.). Worth Publishers, Inc., New York. pp. 735-737.

14. McFarland, B.L. (1983). Studies on the interaction of tomato and Alternaria alternata f. sp. lycopersici. Ph. D. thesis. University of California, Davis.

15. Moore, T.S., Lord, J.M., Kagawa, T. and Beevers, H. (1973). Enzymes of phospholipid metabolism in endoplasmic reticulum of castor bean endosperm. Plant Physiol. 52: 50-53.

16. Nishimura, S. and Kohmoto, K. (1983). Host-specific toxins and chemical structures from Alternaria species. Ann. Rev. Phytopathol. 21: 87-116.

17. Patel, P. and Walker, J.C. (1963). Changes in free amino acid and amine content of resistant and susceptible beans after infection with the halo blight organism. Phytopathology 53: 522-528.

18. Park, P., Nishimura, S., Kohmoto, K. and Otani, H. (1981). Comparative effects of host-specific toxins from four pathotypes of Alternaria alternata on ultrastructure of host cells. Ann. Phytopathol. Soc. Japan 47: 488-500.

19. Siler, D.J. and Gilchrist, D.G. (1982). Determination of host selective phytotoxins from Alternaria alternata f. sp. lycopersici. J. Chromatogr. 238: 167-173.

20. Yoder, O.C. (1980). Toxins in pathogenesis. Ann. Rev. Phytopathol. 18: 103-129.

\section{和 文 摘 要}

川口悦男・Noemi P. OROLAZA・柘植尚志・故 西村正暘・道家紀志：トマトアルタナリア茥枯病菌感染 または AL 毒素処理トマト葉組織におけるアミノ酸とアミン含量の変動

トマトアルタナリア茎枯病菌が感染した葉組織および本菌の宿主特異的毒素である AL 毒素を処理した葉 組織に和けるアミノ酸とアミン含量の変動を感受性と抵抗性品種間で比較検討した。AL 毒素は, 感受性卜 マト品種のアスパラギン酸カルバミルトランスフェラーゼ (ACTase) を阻害すると報告されているが，この 説が正しいとすれば，AL 毒素を処理した感受性植物組織ではアスパラギン酸が蓄積するはずである。しか し，本研究に括いて，AL 毒素を処理した感受性拈よび抵抗性トマト品種葉のアスパラギン酸抒よび他のア ミノ酸含量を定量した結果，少なくとも処理後 24 時間目までは，毒素処理葉と無処理葉の間に差は認めら れなかった。また，茎の基部に本菌胞子を接種して発病させた感受性品種個体において，同一複葉内の病徵 を呈した小葉と無病徵小葉とを比較した場合, むしろ前者でアスパラギン酸の含量は低く, 他のアミノ酸に ついては両者間で差は認められなかった。これらの結果は, AL 毒素の作用が ACTase 阻害以外にあること を示唆する。一方，感受性品種ではエタノールアミンとフォスフォエタノールアミンが毒素処理後 12 から 24 時間の間に著しく蓄積したが，抵抗性品種ではそれらの蓄積が認められなかった。これらアミンの増加 は, 胞子接種した感受性品種個体の発病小葉においても認められた。これらの結果は, AL 毒素が感受性卜 マト品種細胞に和いてアミン関連代謝系の異常を誘起することを示唆する。 